\title{
Conflict resolution in Western Sahara
}

\section{Andreu Solà-Martín ${ }^{*}$}

\section{Abstract}

This paper examines the democratisation agenda laid out by Western governments for the North African region vis-à-vis their Realpolitik conflict containment approach towards the Western Sahara conflict. Western policymakers conceive the United Nations Mission for the Referendum in Western Sahara as a safety net that contains tension in the region and enables geo-strategic and economic partnerships with Algeria and Morocco. This paper underlines that the international community could play a greater role in promoting the long-term stability of the North African region by pursuing innovative policies geared towards addressing the root causes of the Western Sahara conflict.

* Dr. Andreu Solà-Martín is Consultant Lecturer at the Open University of Catalonia (Spain) and Honorary Research Fellow at Peace Studies, University of Bradford (United Kingdom). 


\section{Introduction}

Firstly, this paper attempts to problematise the current strategy of Western States towards democratisation in North Africa by looking at the role played by the Bush administration and the European Union (EU) through the Mediterranean Partnership in the Western Sahara case study. The conflict in Western Sahara dates back to 1975, when the United Nations (UN) decided to sponsor a referendum for the self-determination of the inhabitants of the Spanish Sahara, but Morocco and Mauritania invaded the colony before this was organised (Hodges 1983; Pazzanita and Hodges 1994; Diego Aguirre 1991). In 1988, Morocco and the POLISARIO Front ${ }^{1}$ signed the Settlement Proposals under the auspices of the UN Secretary-General Pérez de Cuéllar and a peacekeeping mission was deployed to supervise the ceasefire between both parties and to facilitate the organisation of the referendum. However, firstly disagreements in relation to the voters list and secondly Moroccan unwillingness to go ahead with any revised version of the UN peace plan involving a referendum with an option for independence have led to the current deadlock. Despite the UN settlement proposals have not been implemented, the United Nations Mission for the Referendum in Western Sahara (MINURSO) effectively monitors the ceasefire and the region remains relatively stable. It can be argued that although the conflict is contained, the political future of the territory remains on hold, and the grievances of Saharawi people are unattended (Shelley 2004; Solà-Martín 2006).

Western Sahara has an estimated population of 273000 inhabitants and several thousand refugees living in Tindouf, Algeria. ${ }^{2}$ The territory has lucrative natural resources including phosphates, iron ore, sand and extensive fishing along the Atlantic Coast. Since 2001, after oil/gas reserves were discovered off-shore Mauritania, Morocco granted reconnaissance licenses to Total and Kerr McGee to explore possible oil/gas reserves off-shore Western Sahara (Olsson 2006).

\footnotetext{
1 Popular Front for the Liberation of Saguía el-Hamra and Río de Oro.

2 The POLISARIO estimates there are 165000 Saharawis living in camps in Tindouf, although the total population of concern assumed by The Office of the United Nations High Commissioner for Refugees (UNHCR) as at January 2009 is 116 561. See: <http:// www.unhcr.org $>$. UNHCR recently requested Algeria to authorise a survey of Saharawi refugees in its territory.
} 
This territory has also a geo-strategic value as a crossroads of traditional trading routes between the Sahel and the Maghreb regions and the Western Saharan harbours along the Atlantic coast can play a prominent role in transoceanic exports and imports. When Spanish colonisation brought urbanisation and an incipient industrialisation through the development of the Saharan phosphor mines, the Spanish Sahara became one of the African colonies with a highest Gross Domestic Product (GDP) per capita (Diego Aguirre 1988). Hence, the exploitation of Western Sahara's natural resources for the benefit of the relatively small number of inhabitants would make an independent Saharan State economically viable.

\section{On democratic discourse and Realpolitik}

The efforts to resolve the Western Sahara conflict have been jeopardised by the difficulties involved in trying to promote a democratic solution for a territory that is militarily controlled by an autocratic regime, the Moroccan government. In this sense, the promotion of a free and fair solution for the Western Sahara conflict should be examined in the context of the ongoing debate on the relationship between democratisation, development and security in the North African region (Zoubir and Benabdallah-Gambier 2004). In recent years, several western initiatives have focused on democracy promotion in the so-called Arab world or broader Middle East, including North Africa. However, this one size fits all approach neglects the extent to which autocracy is deeply ingrained in the political culture and idiosyncrasy of Arab regimes. In Morocco, Tozy has underlined the extent to which the monarch is the religious and political father of the nation and its citizens (Tozy 1999). Moreover, Western efforts at democratisation are tainted by a long history of collaboration between Western powers and the Arab elites dating back to the colonial period. The Arab Human Development Report (2005:12) acknowledged the prominent role played by key foreign powers in the political life of the region:

Arab countries cannot ignore the fact that the world, especially the powerful players in the global arena, will continue to safeguard their interests in the region. Their call for reform in Arab countries falls within this context. 
Upon completion, the Arab Human Development Report (2005) was strongly criticised by the United States (US) and Egyptian administrations and its publication was postponed. This report was written by a group of well-known intellectuals and independent experts from Arab countries. They bluntly criticised their regimes and asked: 'Why, among all the regions of the world, do Arabs enjoy the least freedom?' The document was only released in April 2005 - after elections took place in Palestine, Iraq and Saudi Arabia and Hosni Mubàrak announced political reforms in Egypt. At a conference in Brussels, all these changes were applauded by the Bush administration as steps towards democratisation (United States Government 2005a). In remarks at the 20th anniversary of the National Endowment for Democracy, President Bush announced that the United States would pursue a 'forward strategy of freedom' to promote democracy throughout the Middle East (United States Government 2003). In the State of the Union (United States Government 2005b), President Bush emphasised its administration's commitment to support political, social and economic reforms in the region:

America's actions will result in the spread of democracy in the broader Middle East - an important step that will provide an alternative to terror and violence.

Nevertheless, the US president also pointed out that the US role in the Arab world was not to impose democratic reforms, except when it comes to confronting those who harbour terrorists (United States Government 2005b):

....successful reform in the broader Middle East will not be imposed from the outside; it must be chosen from within. Governments must choose to fight corruption, abandon old habits of control, protect the rights of conscience and the rights of minorities. Governments must invest in the health and education of their people, and take responsibility for solving problems instead of simply blaming others. Citizens must choose to hold their governments accountable. 


\section{The Western Sahara conflict in the context of the War on Terror}

In 2003, the United Nations Secretary-General (UNSG) Special Envoy for Western Sahara, James Baker, resigned after seven years of trying to persuade the parties to move along his diplomatic efforts. In August 2003, Álvaro de Soto replaced William Swing as a Special Representative for Western Sahara. The Peruvian diplomat held a 24-year long career at the UN system. Since 1999, he had been the Secretary-General's Special Adviser on Cyprus. ${ }^{3}$ Nevertheless, Álvaro de Soto was not perceived by the parties as a relevant peacemaker. He certainly lacked Baker's diplomatic weight to move the peace plan forward. In May 2005, Special Representative de Soto left MINURSO and in July 2005, Dutch Diplomat Peter van Walsum was appointed as a UN Special Envoy. After resigning, Baker expressed his views on the matter of Morocco's lack of consent with the operation. He clarified his understanding of MINURSO's role in the context of the US war on terror (1994):

This is a really low intensity, low level dispute. Look, there's no action forcing event in the Western Sahara conflict. Morocco has won the war. She's in possession. Why should she agree to anything? And so she is disinclined to do so. Well, there's one very good reason why she should, because she will never receive the imprimatur of international legitimacy for her occupation of the territory unless she works out some arrangement that is blessed by the international community, blessed by the Security Council, or acceptable to the other party. That's why we work so very hard on the idea of an initial autonomy arrangement with self-government and then a referendum at the end to meet the test, the requirement of the Security Council for SelfDetermination.

Baker's point of view illustrates the extent to which the US diplomatic position in relation to the Western Sahara question is linked to strategic priorities. Morocco prides itself to be the oldest ally of the US. On 20 December 1777, Morocco was the first country to recognise the independence of the United

3 Álvaro de Soto's full Curriculum Vitae is available at United Nations Information Service 2003. 
States of America and in 1786 the Moroccan-American Treaty of Friendship was signed between the two countries. The US military alliance with Morocco was forged during the Cold War period. During the 1950s, bomber bases were built at Nouasseur and Sidi Slimane and they were part of the Strategic Air Command's network of strategic bomber bases pointed at the Soviet Union. Baker sees the history of world order as a dialectic continuum, i.e. the struggle for power between antagonist blocs throughout time. East-West dichotomy has been now bypassed by the war on terror. ${ }^{4}$ Morocco's monarchy played a key role in Africa by supporting the US war against Communism. Now, the US and its security agencies are engaged in supporting Morocco's regime policies against terrorist groups linked to radical salafism. The resolution of the Western Sahara conflict can be, once again, put on hold.

The Western Sahara case is an illustrative example of the extent to which the politics of democratisation promoted by the US administration are constrained by the War on Terror. The policy of 'either you are with us or you are with the terrorists' has led the US to support regimes in the region which rely on the use of coercion to maintain power. Nonetheless, these regimes are geo-strategic allies and economic partners of the West. Due to the security imperatives dictated by the War on Terror, the US administration has strengthened its military cooperation with the states of the Maghreb region. The US has preferential cooperation ties with Morocco (Grupo de Estudios Estratégicos 2004) and recently, there has been an improvement of relations between Algeria and the US government and other NATO members. Algeria and NATO made their first joint naval manoeuvres in the framework of their cooperation on the War on Terror and the Euro-Mediterranean partnership, the so-called Barcelona process (Martín 2002). At the UN level, American policy in relation to the Saharan question seeks equidistance between both major North African economic partners and allies in the War on Terror, Morocco and Algeria. In this sense,

4 Baker on National Programming Service (2004): '[So, Morocco and Algeria to the United States, or perhaps to the international community, are more important why? Because of radical Islam?] - Well, they're joining in the fight against terror. They're helping the United States significantly, both of those countries. And of course they're on different sides of this issue.' 


\section{Conflict resolution in Western Sahara}

US policy in relation to the Saharan conflict is subordinated to its security and economic interests in the region.

The War on Terror led by the US at the global scale has raised geo-strategic stakes in the region. In 2002, fears that the Sahara would become a hiding place for Salafist cells brought the US State Department to promote the so-called PanSahel initiative which was budgeted with more than $\$ 120$ million (International Crisis Group 2005), aiming at giving training and providing anti-terrorist equipment to countries in the region bordering with the Sahara (Mali, Niger, Chad and Mauritania). The Pan-Sahel Initiative (PSI) trained and equipped one rapid-reaction company, about 150 soldiers, in each of the four Sahel states. This initiative was renamed and expanded in 2005 to include as new partners Algeria, Morocco, Tunisia, Senegal and Nigeria. The new Trans-Sahara Counterterrorism Initiative (TSCTI) is conceived as a long-term interagency plan to combat terrorism in Trans-Saharan Africa by helping the participating countries 'to stop the flow of illicit arms, goods, and people through the region' (United States Senate Foreign Relations Committee 2005). The US Special Forces train their African counterparts in military tactics, marksmanship, planning, communications, land navigation and patrolling. The new TSCTI also attempts to foster informational sharing and operational planning between the states of the region.

Without a doubt, the US-led War on Terror is shaping security dynamics in North Africa, by enlarging states' capabilities to clamp down on anti-terrorist groups and political dissenters. Some experts have warned about the extent to which the militarisation of the Saharan desert may endanger nomadic tribes' livelihood and particularly their means of subsistence. Moreover, this initiative strengthens the capabilities of security forces that have an extensive record of human rights violations (Mcelroy 2004; Keenan 2004). In Atar, Mauritania, near the southern border of the Western Sahara territory, the US army has carried out military training exercises with the Mauritanian army in a period of political turmoil in the country. On 3 August 2005, a coup d'état took place; the long-serving dictator Maaouya Ould Sid'Ahmed Taya was ousted by the military of Mauritania and replaced by the Military Council for Justice and Democracy. Since the pan-Sahel initiative was put in place, the Moroccan press has denounced the presence 
in Tindouf ${ }^{5}$ of members of radical Islamic organisations in an unsuccessful attempt orchestrated by Moroccan power holders to persuade US to target POLISARIO as an enemy in the War on Terror (Anon 2004; Anon 2007).

Meanwhile, in October 2004, the African Union (AU) members met in Argel in a summit on terrorism which set up an African Centre for the Study and Research on Terrorism. This new centre will provide information exchange on terrorist cells operating in AU member states (Africa Union 2004). This was preceded by an agreement between the Algerian government and the US government to establish formal dialogue on military issues in June 2004. While the influence of Western security policies grows in the Sahara, terrorist activities have not ceased. In Algeria, clashes between the army and unidentified armed groups left several thousand victims throughout the 2000's decade, with a situation of protracted violence in the provinces nearby Algiers and other northern provinces. Likewise, clashes have continued up to date and the efforts of Bouteflika's government towards national reconciliation are unable to satisfy Algerian citizenship, largely sceptical on promises such as those expressed by the mighty General Mohamed Lamari. He resigned in June 2004 and it was ascertained that the army was no longer willing to being involved in the country's political life (Cherfaoui 2004).

In Morocco, terrorists hit Casablanca on 16 May 2003 and Moroccan citizens were also involved in Madrid's train bombings on 11 March 2004. Since 2003, thousands of suspect terrorists have been jailed by Moroccan security forces. Moroccan and International Human Rights organisations have denounced arbitrary arrest, long pre-trial detention, ill-treatment and torture (Cembrero 2004; Amnesty International 2004-2008). In the 2007 Presidential and Legislative elections, the moderate Islamist Justice and Development Party (PDJ) has consolidated its 2003 gains, becoming the second political force in the country, and for the first time the Moroccan monarchy permitted PDJ to have candidates in all circumscriptions. Nonetheless, the turnout in the 2007 election was only $37 \%$ and Islamist activists remain very influential political agents. In particular, Sheik d'Abdeslam Yassine's civic movement Justice and Charity

5 Tindouf is an Algerian town where both the Saharawi refugee camps and the POLISARIO headquarters are based. 
(al-Adl wa al-Ihssan) has succeeded in galvanising support for a non-capitalist, so-called humanitarian, socio-economic project based on the Islamic Message and the instauration of an Islamic Republic (Yassine 2005).

\section{The European Union democratisation agenda in North Africa}

The European Union (EU) policy towards North Africa has been articulated around the so-called Euro-Mediterranean partnership and the Barcelona declaration adopted at the Euro-Mediterranean Conference at the end of November 1995. In particular, in the framework of the so-called political and security partnership and the efforts to establishing a common area of peace and stability, the Euro-Mediterranean partners agreed that:

The peace, stability and security of the Mediterranean region are a common asset which they pledge to promote and strengthen by all means at their disposal (The Euro-Mediterranean Partnership 1995).

Concerning conflict resolution in the region such as Western Sahara, the EuroMediterranean partners undertook to:

Settle their disputes by peaceful means, call upon all participants to renounce recourse to the threat or use of force against the territorial integrity of another participant, including the acquisition of territory by force, and reaffirm the right to fully exercise sovereignty by legitimate means in accordance with the UN Charter and international law (The Euro-Mediterranean Partnership 1995).

France and Spain, alongside the US are the main economic partners of Morocco and Algeria. The EU is the main donor of humanitarian aid towards Saharawi refugees. However, the EU does not pool resources directly towards conflict resolution efforts in Western Sahara. These resources are mostly to support humanitarian programs in the camps of Tindouf (Algeria). Since 2000, the European Parliament (EP) has maintained an active stance through its group 'Intergroup Peace for the Saharawi People', under the presidency of the German socialist member of the European Parliament, Margot Kessler. This group 
has been active in lobbying the UN and EU governments to promote conflict resolution in Western Sahara (Intergroup Peace for the Saharawi People 2004). However, the European Commission (EC) has not promoted diplomatic initiatives such as the Road Map for Peace in the Middle East towards North Africa. According to Álvaro Iranzo (European Institute of the Mediterranean 2005), General Director of the Spanish Ministry of Foreign Affairs, in charge of policy implementation towards the Mediterranean, Middle East and Africa, the Spanish Foreign Ministry is not in a position to become directly involved in top down diplomacy initiatives in the Western Sahara conflict as its main policy in relation to the North African area is the promotion of stability and equally good neighbourhood with the Algerian and Moroccan authorities. The Spanish administration is fearful that an active policy towards the Saharan question may jeopardise these efforts.

Differences among EU members in relation to common foreign and security policy in the Saharan case were brought to public in 2003, when most countries supported the new Baker plan II, ${ }^{6}$ but France remained sized to its stance to support the Moroccan administration which was unwilling to go along Baker's new initiative. Despite France's reluctance to support the American plan, the French delegation did not finally veto the Security Council Resolution on the Baker plan II (United Nations Security Council Resolution 1495 2003). It can be argued that there is a gap between the Saharan policy supported by the group of European parliamentarians and those policies promoted by EU State members. In the Saharan case, the French government has traditionally supported the Moroccan position and this hinders consensus building. In this sense, the extent to which EU common foreign policies can be successful in the second pillar framework is debatable because in many cases EU states' Realpolitik is at odds with the promotion of international law and human rights. The lobbying role played by the EU Parliament and the institutional development of a common foreign and security policy, as specified in the Treaty of Lisbon (Assembly of Western European Union 2008), could eventually shorten the gap between

6 The new Baker Plan was based on international law and the promotion of a democratic process through which all citizens from Western Sahara would freely choose their government and state affiliation. 


\section{Conflict resolution in Western Sahara}

European member states' agendas and the efforts to institutionalise a common European policy towards international conflict.

Since March 2004, the socialist government of Spain has worked on improving diplomatic relations between Spain and Morocco. These relations had gone bitter since the Parsley Island crisis in July 2002. In August 2004, there was a joint military operation in Haiti with forces from both countries. The first visit of Spanish President José Luis Rodriguez Zapatero to Morocco was in April 2004 and he mentioned Spanish willingness to promote negotiations between both parties in the framework of a regional agreement between all states involved in the Western Sahara conflict. Zapatero's views raised concerns amongst members of the Spanish associations of solidarity with the Saharawi people - as Zapatero has not been clear on the UN role in resolving the Western Saharan conflict (Cruz 2004).

On the other hand, Kessler (2004) has criticised Spanish diplomatic acquiescence to French policy and has pointed out that 'this kind of apparent diplomatic behaviour of the new Spanish government is difficult to understand and to contribute for a serious European solution for the conflict, it seems more to respond to the French wish to hide the decolonisation file of the Sahara under a false and apparent normal military occupation of this Non Self-Governing Territory'. The Spanish government did not support a non-binding resolution of the UN General Assembly (UNGA) Fourth Committee, the Special Political and Decolonisation Committee to support the Baker plan proposed by Algeria in October 2004 (United Nations General Assembly 2006).7 This move was unprecedented: for the first time since 1988, Spain did not support a UN peace initiative to resolve the Saharan conflict. Thus, Spanish diplomacy is working towards a rapprochement between Algeria and Morocco as a means to facilitate a regional solution to the conflict based on providing autonomy for Western Sahara within Morocco (Segovia 2004). While Western foreign policy discourses emphasise democratisation as key to conflict resolution in the Arab world, their

7 On 13 October 2006, Spain and France abstained in the UNGA resolution on Western Sahara. This resolution was passed with 77 votes in favour and 72 abstentions. $14 \mathrm{EU}$ members voted in favour, namely Austria, Belgium, Denmark, Estonia, Finland, Germany, Holland, Hungary, Ireland, Poland, Slovakia, Slovenia, Sweden and United Kingdom. 
Realpolitik is guided by national security concerns which contribute to some extent to protract the Western Sahara conflict.

\section{A war on hold}

On 4 July 2004, a group of ex-combatants from POLISARIO and youngsters from the refugee camps released a manifesto calling for a collective resignation of the POLISARIO leadership and urging them to organise democratic elections to elect new representatives. In this communiqué, the group expressed disappointment with the leadership of POLISARIO and their management of the peace process. Among other things, the communiqué criticised the progressive dismantling of the Saharawi Popular Army of Liberation (SPLA) and a lack of internal democracy and freedom of expression within the movement. The upheaval of critical voices within POLISARIO can be explained by the Western Saharan perception of progressive marginalisation of their claims in the international arena. This communiqué criticised the leadership of POLISARIO for neglecting war martyrs and questioned the efforts made by the international community to achieve a final solution for this conflict. This opposition group may not be followed by a substantial number of Western Saharan people in the refugee camps of Tindouf in Algeria. Nevertheless, its claims illustrate the frustration felt by a large sector of Saharawi society with the way the peace process unfolded since its inception in 1988.

On the other hand, this frustration has been also echoed within the POLISARIO leadership. Some top officials talk again about resuming the hostilities and they criticise UN peacemaking efforts (Lmrabet 2004). Western Saharan people's perception is that time is running in favour of Morocco, which is investing in the so-called Southern Provinces to harbour the so-called Moroccan settlers, as well as exploiting the Western Saharan natural resources such as phosphor mining and fisheries. Some sectors of Western Saharan society are critical about decisions made by the POLISARIO leadership during the negotiations on the organisation of the Referendum. As some studies on MINURSO point out, POLISARIO policy in relation to the identification of voters and other peace plan provisions was to accept progressively the introduction of new variations to the settlement plan 


\section{Conflict resolution in Western Sahara}

which were demanded by the Moroccan counterpart since 1988 (Solà-Martín, 2006). It can be argued that POLISARIO's flexibility has helped the Moroccan party to believe in its chances to maintain its control over the Western Sahara. On the other hand, it can also be argued that POLISARIO's cooperation with MINURSO was its only defence against Moroccan obstructionist tactics to the implementation of the peace process. POLISARIO adopted a flexible approach to the implementation of the peace agreements by acquiescing to Moroccan demands on the identification of voters for the Referendum in order to reach a political solution to the conflict by peaceful means - a solution that would be supported by the international community. Nevertheless, to date POLISARIO's expectations remain unfulfilled.

In this context, disagreements between the Algerian and the Moroccan government have resulted in an increase of tension between both countries, each of whom accuses the other of unwillingness to negotiate a resolution for the Saharan conflict. Tensions between the governments of Argel and Rabat reached a peak in October 2004 when Algeria deployed its army along the border with Morocco, in a move which the Moroccan press described as belligerent towards Morocco. At last, Argel decided not to organise the manoeuvres which had been planned to celebrate Independence War $50^{\text {th }}$ anniversary in order to reduce mounting tension with Morocco (Borowiec 2004).

In the current context, the Moroccan monarchy uses the Saharan conflict as a scapegoat to divert attention from Morocco's internal problems linked to poverty and unequal access to political participation. In turn, the Saharan conflict brings cohesion around the king's mighty power as a uniting force against perceived hostile external forces, e.g. Algeria or the UN, who are willing to claim the so-called kingdom's Southern Provinces. In the last decade, some progress has been made in democratisation efforts in Morocco - such as a relative enhancement of media freedom and a sizeable flourishing of civil society organisations. The Equity and Reconciliation Instance (IER) promoted by the king has organised summary processes to clarify and compensate victims of political repression. Nevertheless, Amnesty International has warned that this openness and enhancement of civil liberties has not affected to the same extent the Western Sahara territory (Amnesty International 2004). For example in 2003, 
the Saharan Section of the Moroccan Forum for Truth and Justice was banned and its members were accused of displaying pro-independence slogans and of supporting international organisations cooperating with the Saharawi people such as The European Conference of Coordination Support to the Saharawian People (EUCOCO) coordinated by the Belgian Pierre Galand (Kingdom of Morocco, Department of Justice 2003).

Meanwhile, MINURSO does not investigate human rights violations which take place in the territory of Western Sahara. The mission's strength was reduced to a minimum expression since the negotiations on the Settlement Proposals were suspended at the end of 2000. Subsequently the mission focused on coordinating confidence-building measures agreed to by both parties: the promotion of peacebuilding through family visits between Saharawi families divided by the sand berm and the opening of new phone lines between the refugee camps and the cities located west of the sand berm.

\section{The United Nations diplomatic efforts to resolve the Western Sahara conflict}

In 2000, the UN Secretariat decided to give up the efforts towards the completion of the identification process, arguing that the parties were not ready to compromise, and suggested that the parties 'explore ways and means to achieve an early, durable and agreed resolution of their dispute' (United Nations Security Council Resolution 1292 2000).8 On 20 June 2001, Baker presented the so-called Framework agreement on the status of Western Sahara (Baker Plan I) that contained provisions for a 'confirmatory' referendum within the five-year period following the implementation of this agreement. However, the new plan did not specify what alternatives were to be voted on, in case the plan was not approved. Furthermore, those options envisaged in the Settlement Proposals, for independence or integration, were not even contemplated. The Baker Plan I was rejected by the POLISARIO Front who was still advocating the implementation of the UN Settlement Proposals. In 2003, after consultations with the parties, Baker reformulated his proposal by putting forward the so-called Peace plan

8 This expression was first used in United Nations Secretary General Report S/2000/131 2000. 


\section{Conflict resolution in Western Sahara}

for self-determination of the people of Western Sahara (Baker Plan II). The referendum would take place 5 years after the effective date of the plan that would also include the ballot options previously agreed to in the Settlement Proposals, i.e. independence or integration of Western Sahara into Morocco. The plan provided that all Moroccan nationals living in the area of the Western Sahara territory controlled by Morocco since 1999 - who presently outnumber native Western Saharans - would vote in the referendum. For the first time, POLISARIO approved this alternative to the implementation of the Settlement Proposals. However, the plan was not approved by the UN Security Council because Morocco reacted negatively to POLISARIO's unexpected eagerness by opposing the Baker Plan II. As a result of this deadlock, in June 2004, Baker resigned as the UN Secretary-General's Personal Envoy for Western Sahara and there was a long impasse in the UN mediated negotiations. Out of frustration, the so-called Saharawi Intifada, a popular uprising, was unleashed in the Western Sahara controlled by Morocco since May 2005. Protesters demanded political and socio-economic rights for Western Saharan people.

On 11 April 2007, Morocco submitted to UN Secretary-General Ban Ki-Moon a new initiative along the lines of the Baker Plan I. Morocco's new proposal, called 'Moroccan Initiative For Negotiating An Autonomy Statute For The Sahara Region', would grant autonomy for the Sahara within the framework of the Kingdom's sovereignty and national unity. The Government of the Sahara autonomous Region would exercise similar powers over local administration to those enumerated in the Baker plans I and II. The Region's autonomy statute would be submitted to the regions' populations in a free referendum. However, the proposal did not clarify whether this alleged self-determination exercise would enable the Western Saharan people to choose either independence from, or integration into Morocco. On the other hand, POLISARIO presented an alternative plan stressing its traditional views regarding the implementation of the self-determination principle through a referendum monitored by the UN. Since June 2007, the UN Secretary-General's Personal Envoy for Western Sahara, Peter van Walsum of the Netherlands, embarked on four rounds of negotiations with the parties to discuss both initiatives in Manhasset, Long Island (United States). In April 2008, the Security Council met in a closed 
session to discuss the lack of progress in the negotiations and Peter van Walsum presented a document in which he claimed that an independent Western Sahara was not a realistic option. Van Walsum's pro-Moroccan stance was strongly criticised by the POLISARIO leadership and on 4 August 2008 Saharawi Arab Democratic Republic (SADR) President Mohamed Abdelaziz sent a letter to the Secretary-General of the United Nations, Ban Ki-Moon, in which he stated that Van Walsum had disqualified himself from mediating between the parties. In September Ban Ki-Moon appointed US diplomat Christopher Ross as his new special envoy in Western Sahara. Ross has a long experience in the Arab world and his appointment was welcomed by the POLISARIO leadership who supports a greater US involvement in brokering a lasting solution for the conflict in Western Sahara.

\section{The new Obama administration: A window of opportunity}

In 2009, the new Special Envoy for the UN Secretary-General, Christopher Ross, was deployed to the region to make some progress towards a peaceful solution to the conflict, but prospects are grim since any diplomatic solution pursued so far would entail the parties making concessions on the core issue of sovereignty. The status quo is a blessing for the occupying power and a curse for the liberation movement. In July 2009, US President Barack Obama wrote a letter to the King of Morocco, Mohammed VI, mainly on the Middle East peace process. Obama also requested his cooperation towards a diplomatic solution on the matter of Western Sahara under UN auspices (United States Government 2009):

I share your commitment to the talks under the auspices of the United Nations as the appropriate framework to reach a mutually acceptable solution, and I hope that Christopher Ross, a seasoned diplomat with wide experience in the region, will promote a constructive dialogue between the parties...My government will work with yours and others in the region to achieve an outcome that meets the people's need for transparent governance, confidence in the rule of law, and equal administration of justice...

In this letter, Obama omitted to mention the autonomy proposal laid out by Mohammed VI in 2007. The latter proposal had been praised by the Bush 


\section{Conflict resolution in Western Sahara}

administration in its correspondence with the King of Morocco on the Western Sahara question. After the UN Security Council adopted resolution 1871 on Western Sahara, on 30 April 2009, US Ambassador to the UN Susan Rice did not refer to Morocco's autonomy proposal either. Hence, it is apparent that the new US administration is intending to reverse the former US administration policy of endorsing Morocco's proposal to settle the conflict. It has been actually pointed out unofficially by a Spanish diplomat that Obama's administration is now working on a new proposal which would draw on the Baker Plan (Cembrero 2009). The Saharawi Arab Democratic Republic (SADR) is a full member of the African Union whilst Morocco has been long ostracised in the African continent because of its refusal to allow the free will of the people of Western Sahara. Obama has become a flag-bearer of policy change because of his endorsement of principles of democratic accountability and transparency. Perhaps, this is the last opportunity to decolonise the last colony of Africa before Moroccan occupation becomes a fait accompli. However, previous experience from influential US policy makers such as James Baker demonstrates that Morocco is simply not interested in organising a referendum in Western Sahara. Paradoxically, only a solution that is consistent with UN doctrine and international law can break the current deadlock.

\section{Moving towards conflict resolution in Western Sahara}

Shifting the diplomatic agenda beyond containment policies pursued by the US and EU members towards a conflict resolution approach can be the stepping stone towards sustainable peace in the region. MINURSO and Western policies of conflict containment linked to the US-led War on Terror have not promoted democratisation in Western Sahara. Wishful thinking perhaps, but this section lays out a strategy to bridge the gap between the democratisation rhetoric of American and European policymakers and the reality of western diplomatic efforts in the region.

The international community needs to engage in an active diplomatic strategy to enhance support for the recognition of the Saharawi Arab Democratic Republic (SADR) as a sovereign independent state and new member of the United 
Nations - pending a final solution for the territory based on the implementation of UN Resolution 1514 and the UN doctrine on Non-Self governing territories i.e. a self-determination referendum. The Organisation of African Unity (OAU) accepted the SADR as a full member in 1982. Most OAU members recognised the former Spanish Sahara, SADR, as a sovereign state - applying the OAU doctrine on the sacrality of state borders inherited from colonialism. From the time of the OAU inception, state sovereignty and territorial inviolability were bedrock principles of the organisation. Respect for territorial integrity of member states led them to accept the principle of uti possidetis with regard to state boundaries. Uti possidetis provides that borders that were determined by colonial powers prior to independence were not to be altered and would form the permanent frontiers of the independent African states. ${ }^{9}$ Since 2001, the OAU was dissolved in favour of a new organization, the African Union (AU), and some reconceptualisation of the role of the organisation was undertaken, mainly regarding its role in humanitarian crises. Nevertheless, uti possidetis remains a bedrock principle as envisaged in Article 4 of the AU Constitutive Act. According to article 4, the Union shall function in accordance with sovereign equality and interdependence among member states of the $\mathrm{AU}$ and respect of borders existing on achievement of independence (Gardner 2000).

Since the peace process became deadlocked, some states that had recognised the SADR during the Cold War period have withdrawn their recognition or put it on hold until the referendum process comes to an end. Some among the poorest African nations have withdrawn recognition after reaching political and economic cooperation agreements with the Moroccan government. ${ }^{10}$ On the other hand, on 15 November 2004, the Republic of South Africa announced its official recognition of the Saharawi Arab Democratic Republic (SADR), according to a joint communiqué signed by the Saharawi Minister for Foreign Affairs, Mr. Mohamed Salem Ould Salek and Mrs. Nkosazana Dlamini-Zuma,

9 This principle of uti possidetis was implicitly recognised in Article 3, Paragraph 3 of the OAU Charter.

10 Former President of Liberia Charles Taylor withdrew SADR recognition in 1997. Equatorial Guinea withdrew SADR recognition in 1980. In 2002 the US-supported postTaliban government of Afghanistan withdrew SADR recognition. 


\section{Conflict resolution in Western Sahara}

South African Minister for Foreign Affairs. This communique stated that this South African initiative 'will bring a highly valued contribution to the return of peace and stability in the northern part of our continent through a fair and balanced approach towards all peoples of the region' (Sahara Press Service 2004). Therefore, South African policy intended to galvanise international support towards recognition of the SADR and the promotion of conflict resolution in the region.

Western European states have never recognised SADR, but there are some indications that some of these countries are reconsidering their policies on this issue. In Norway, there is a growing consensus among the ruling coalition parties that SADR recognition is the way forward to break the current diplomatic stalemate. In January 2007 the Norwegian Liberal Party adopted a resolution demanding official Norwegian recognition of SADR. On 22 April 2007, the National Council of Socialist Left Part (SV) issued a declaration urging Norway to recognise the SADR. The declaration also pointed out that Norwegian business operating in the Western Sahara controlled by Morocco contributed to sustain the occupying power and advised the government to discourage Norwegian companies to invest or commercialise goods in Western Sahara till the conflict is resolved. Elsewhere in Europe, the recognition of Western Sahara is currently being discussed as a policy option. In April 2007, at its annual congress, the EU association of liberal youth parties, European Liberal Youth (LYMEC), ${ }^{11}$ issued a resolution calling on European governments to formally recognise the SADR as an independent state. The liberal parties agreed to put pressure on the mother parties to pursue this goal.

A workable and lasting peace strategy for Western Sahara will only succeed if the international community assumes a more robust role in clarifying human rights violations and promoting confidence-building measures so that the refugees can return to the Western Sahara territory. Since Emmanuel Rocounas resigned in 1999 as MINURSO's International Jurist to clarify Saharan disappearances, this post remains vacant (United Nations Secretary General Report S/1999/954 1999).

11 LYMEC has member organisations in 37 European countries and almost 250000 individual members throughout Europe. 
An unpublished report produced by the UN Office of the High Commissioner for Human Rights (OHCHR) on Western Sahara in 2006 stressed the extent to which human rights in Western Sahara can only be effectively protected by promoting the organisation of a referendum for the self-determination of the Western Saharan people (OHCHR 2006). This report was kept secret, once more, due to diplomatic fears that the report's findings would upset the Moroccan regime. Nevertheless, its conclusions certainly support the argument laid out in this paper that UN policy in relation the Sahara needs to move towards Western Saharan statehood. Only this option provides the basis for protecting Western Saharan people from political repression, while ways are devised to work on the parties' consent for a referendum to take place across the territory to define whether the territory of Western Sahara becomes an independent state or is integrated into Morocco. Time is ripe for the Obama administration to work in partnership with other members of the Security Council, African States, the EU and Spain in order to endorse a new mandate for MINURSO based on Chapter VII of the UN Charter. MINURSO should play a new role to protect the people of Western Sahara from human rights abusers and only then a peaceful and lasting solution based on decolonisation doctrine can be pursued: the long overdue self-determination referendum should be monitored by UN military and civilian observers across the Western Sahara territory.

\section{Concluding remarks}

This paper argues for a strategy of maximising efforts to implement a UN plan for the self-determination of the Western Saharan people, advocating international recognition of SADR. Renewed efforts by the international community to achieve this end will only be fruitful if Western countries in cooperation with the AU show political eagerness to move the process forward. There is a wide range of literature on post-Cold War peacekeeping and humanitarian intervention that stresses the extent to which these practices involve exporting Western liberal democratic practices to war-torn societies as a means of conflict resolution (Duffield 2001; Bellamy et al. 2004). However, the Western Sahara case illustrates the extent to which power politics have overshadowed conflict resolution efforts in North Africa. Morocco bases its strategy on blocking any 
solution that challenges its control over the Western Sahara. On the other hand, from the onset of the peace process, POLISARIO has supported all $\mathrm{UN}$-sponsored peace proposals to resolve the Western Sahara conflict. To date, the prospects for a broader involvement of the West in the promotion of Western Saharan people's rights in the current international framework dominated by the US-led War on Terror are rather grim. This is a dangerous situation and conflicts in Israel/Palestine or Cyprus provide strong evidence that protracted military occupations of disputed territories lead to deeply divided and polarised societies. The Western Sahara conflict has been contained but not resolved and this dispute will remain a roadblock for the promotion of economic and political cooperation in the Maghreb region unless courageous diplomatic initiatives such as greater international backing for Western Saharan statehood are put on the peace table.

\section{Sources}

African Union 2004. Declaration of the Second High-level Intergovernmental Meeting on the Prevention and Combating of Terrorism in Africa. (Mtg/HLIG/Conv.Terror/Decl. II), African Union. Available from: <http://www.africa-union.org $>$

Amnesty International 2004, 2005, 2005, 2007, 2008. Morocco/Sahara Occidental Section in Amnesty International Annual Report. London, Amnesty International. Available from: $<$ http://www.amnesty.org $>$

Anon 2004. Une probable interconnexion du Polisario avec le réseau de Ben Laden lors d'une Conférence à l'Université de Genève : des experts mettent en evidence. Le Matin du Sahara, 1 April.

Anon 2007. Polisario : Tentation Islamiste. Editorial, Le Matin du Sahara, 21 February.

Arab Human Development Report 2005. New York, United Nations Development Programme (UNDP).

Assembly of Western European Union 2008. Treaty of Lisbon amending the Treaty on European Union and the Treaty establishing the European Community, Provisions concerning the Common Foreign and Security Policy (CFSP), including the Common Security and Defence Policy (CSDP) arranged by topic, A/WEU [2007] DG 7 Rev 1 . The Interparliamentary European Security and Defence Assembly. Available from: $<\mathrm{http}: / /$ www.assembly-weu.org>

Bellamy, A., P. Williams, M. Pugh, O.P. Richmond, T. Vayrynen, R. Bleiker and E. Stamnes 2004. Peace operations and global order. International Peacekeeping, 11 (1), pp. 1-226.

Borowiec, A. 2004. Algeria cancels parades to ease tension. The Washington Times, 1 November. 
Cembrero, I. 2004. La Revisión del Pasado en Marruecos Abre un Debate sobre los Actuales Abusos a Islamistas. El País, 23 December.

Cembrero, I. 2009. Obama se desmarca de la solución que ofrece Rabat para el Sáhara. El País, 15 July.

Cherfaoui, Z. 2004. Lamari : "J'ai quitté mes fonctions à ma demande ». El Watan, 16 August.

Cruz, M. 2004. Abdelaziz Reclama a Rodríguez Zapatero más Compromiso en Defensa del Pueblo Saharaui. El Mundo, 26 November.

Diego Aguirre, José R. 1988. Historia del Sahara Español: La Verdad de una Traición. Madrid, Kaydeda.

Diego Aguirre, José R. 1991. Guerra en el Sáhara. Madrid, Istmo.

Duffield, M. 2001. Global governance and the new wars: The merging of development and security. London, Zed.

European Institute of the Mediterranean 2005. Seminar: Solutions for the Sahara; Western Sahara in the dynamic geopolitics of the Maghreb, 3-4 June 2005. Barcelona, European Institute of the Mediterranean.

Gardner, A.M. 2000. Self-determination in the Western Sahara: Legal opportunities and political roadblocks. International Peacekeeping, 7 (2), pp. 115-138.

Grupo de Estudios Estratégicos 2004. Notas. Grupo de Estudios Estratégicos (GEES), No. 17.

Hodges, T. 1983. Western Sahara: The roots of a desert war. Westport, Conn., Lawrence Hill in association with Croom Helm.

Intergroup Peace for the Saharawi People 2004. Press Release, 29 April 2004. Strasbourg, European Parliament.

International Crisis Group 2005. Islamist terrorism in the Sahel: Fact or fiction? 31 March 2005. Africa Report, 92. Available from: <http://www.crisisgroup.org >

Keenan J. 2004. Terror in the Sahara: The implications of US imperialism for North and West Africa. Review of African Political Economy, 31 (101), pp. 475-496.

Kessler, M. 2004. European Parliament Intergroup Peace for the Saharawi People. Press release, Brusssels, 29 April 2004. Available from: <http://www.arso.org >

Kingdom of Morocco, Department of Justice 2003. Document No: 80.G/2000. Layooune: Department of Justice, Appeal Court of Layooune, First Instance Tribunal of Layooune.

Lmrabet, A. 2004. Interview with SADR President Mohammed Abdelaziz. El Mundo, 14 November.

Martín, I. 2002. Acuerdo de Asociación UE-Argelia: ¿Inserción económica o reinserción política? Nación Árabe, 47, pp. 33-39.

Mcelroy, D. 2004. US extends the war on Islamic terror to the Sahara Desert. The Telegraph, 6 June. 


\section{Conflict resolution in Western Sahara}

National Programming Service 2004. Sahara Marathon: Host Interview Transcript [Baker, J.]. Interview., USA: National Programming Service (PBS), Wide Angle program. Available from: <http://www.pbs.org >

OHCHR (Office of the United Nations High Commissioner for Human Rights) 2006. Report of the OHCHR Mission to Western Sahara and the Refugee Camps in Tindouf 15/23 May and 19 June 2006. Unpublished Report. Available from: <http://www.afapredesa.org >

Olsson, C. ed. 2006. The Western Sahara conflict: The role of natural resources in decolonization. Current African Issues 33. Uppsala, Nordiska Afrika Institutet.

Pazzanita, Anthony G. and T. Hodges 1994. Historical dictionary of Western Sahara. African Historical Dictionaries no. 55. London, Scarecrow Press.

Sahara Press Service 2004. Pretoria's recognition of SADR 'reflects' the legitimacy of Saharawi people's struggle for self-determination. Available from: $<$ http://www.spsrasd.info $>$

Segovia, C. 2004. España apoya a Rabat en la ONU en un Voto sobre el Sáhara. El Mundo, 20 November.

Shelley, T. 2004. Endgame in the Western Sahara: What future for Africa's last colony? London, New York, Zed Books.

Solà-Martín, A. 2006. United Nations Mission for the Referendum in Western Sahara. Lewiston (N.Y), Lampeter, Edwin Mellen Press.

The Euro-Mediterranean Partnership 1995. Barcelona declaration, adopted at the EuroMediterranean Conference, 27-28 November 1995.

Tozy, M. 1999. Monarchie et Islam Politique au Maroc. Paris, Presses de la Fondation nationale des sciences politiques.

United Nations General Assembly 2006. The draft resolution on the question of Western Sahara (document A/61/415), Sixty-first General Assembly Plenary 79th Meeting (PM), Annex XII. Available from: <http://www.un.org >

United Nations Information Service 2003. Biographical Note, Secretary-General Appoints Álvaro de Soto of Peru Special Representative for Western Sahara. (SG/A/853 BIO/3521) United Nations Information Service. Available from: <http://www.un.org >

United Nations Secretary General Report 1999. (S/1999/954) New York, United Nations. Available from: $<\mathrm{http}: / /$ www.un.org $>$

United Nations Secretary General Report S/2000/131 2000. New York, United Nations. Available from: $<\mathrm{http}: / /$ www.un.org $>$

United Nations Security Council Resolution 1292 2000. New York, United Nations. Available from: <http://www.un.org >

United Nations Security Council Resolution 1495 2003. New York, United Nations. Available from: <http://www.un.org > 
United States Government 2003. Fact Sheet: President Bush calls for a 'Forward Strategy of Freedom' to promote democracy in the Middle East. The White House: Office of the Press Secretary. Available from: <http://www.whitehouse.gov>

United States Government 2005a. President Discusses American and European Alliance in Belgium Concert Noble. Brussels. The White House: Office of the Press Secretary. Available from: <http://www.whitehouse.gov>

United States Government 2005b. The State of the Union, 2005. President George W. Bush.

United States Government 2009. President Obama's letter to King Mohammed VI. Summary available from: <http://www.magharebia.com>

United States Senate Foreign Relations Committee 2005. Trans-Sahara Counterterrorism Initiative Statement of General James L. Jones, USMC Commander, United States European Command before the US Senate Foreign Relations Committee. Available from: $<$ http://foreign.senate.gov>

Yassine, N. (Spokesperson of Justice and Charity) 2005. Conference Islam and Democracy, 22 April 2005. Berkeley, University of California. Available from: <http://webcast.berkeley. edu>

Zoubir, Y. and K. Benabdallah-Gambier 2004. Morocco, Western Sahara and the future of the Maghrib. Journal of North African Studies, 9 (1), pp. 49-77. 